\title{
Eco-design methods for developing new products based on QFD: a literature analysis
}

\author{
Fabio Neves Puglieri ${ }^{a}$, Aldo Ometto ${ }^{a}$, Paulo Augusto Cauchick Miguel ${ }^{b}$ \\ University of Sao Paulo \\ bFederal University of Santa Catarina \\ e-mails: puglieri@usp.br; aometto@sc.usp.br; cauchick@deps.ufsc.br
}

\begin{abstract}
With the increasing pollution and consumption of natural resources due to the growing demand for manufactured goods, a number of eco-design methods aimed at achieving environmental suitability of products have been proposed since the 1990's. This study aimed at examining QFD applications that ensure the development of more environmentally suitable products. To this end, a systematic literature review of eco-design requirements was performed. This allowed for the identification of characteristics that the methods must meet from the environmental point of view and application. For this review on the eco-design requirements, 17 publications based on QFD were analyzed. One of the main results from the eco-design QFD analysis was the absence of the traditional QFD characteristics such as quality plan, design quality, and deployment of technical requirements into components, processes, etc. Another result determined through the analysis was that many authors consider only the house of quality as the whole QFD when they are developing environmental methods. In conclusion, most of these methods cannot be considered QFD, and often do not really promote environmental benefits as well.
\end{abstract}

Keywords: eco-design, environmental issues, QFD.

\section{Introduction}

Environmental issues have been introduced in new product development especially from the 90's. The terms usually referred to those are eco-design or design for environment. Eco-design can be defined as product development that incorporates environmental concern considering environmental requirements that allow reducing environmental impacts in product life cycle (BAKKER, 1995). To improve environmental aspects of products a number of practices have been considered such as simple methods, tools, and guidelines to more complex techniques such as life-cycle management (BOVEA; WANG, 2007).

Among the eco-design practices, some of them are adapted from methods and tools already available in new product development body of knowledge. One of methods and tools that have emerged in the literature is QFD (quality function deployment). There have been a large number of publications on 'environmental QFD' in the past ten years when compared to other methods and tools. One of the main advantages of using QFD in eco-design is the possibility to consider environmental requirements when developing a new product by translating those requirements into design specifications (MASUI; SAKAO; INABA, 2001).

Although the benefits of eco-design methods some authors argue that not always new products are environmentally better (RITZEN; LINDAHL, 2001) as well as eco-design practices are not necessarily applied in the product development (KNIGHT; JENKINS, 2009). In this sense, this paper aims at analyzing a number of publications that propose eco-design methods based on QFD. To do so, a systematic literature review was conducted. Twelve research strings related to the terms 'QFD and 'ecodesign', 'design of environmental', and others were used to search 7 data bases. As a result, 17 methods based on QFD published between 1993 and 2009 were identified.

The paper is organized as follows: the next section presents the research design followed by the description of eco-design methods based on QFD. The third section analyzes the literature and the final one establishes some concluding remarks and future work.

\section{Research design}

This work has adopted a systematic literature review that involves specific objectives that allow a critical analysis of data collected from the literature, solve possible conflicts of published works as well as identify research questions for further work (BIOLCHINI et al., 2005). Firstly, research strings were identified (Table 1). The main objective was 
Table 1. Research strings for eco-design methods based on QFD.

\begin{tabular}{|l|l|}
\hline QFD ecodesign & Quality function deployment ecodesign \\
\hline QFD eco-design & Quality function deployment eco-design \\
\hline QFD DfE & Quality function deployment design for environment \\
\hline QFD design for environment & Environmental QFD \\
\hline Quality function deployment DfE & Environmental quality function deployment \\
\hline QFD ambiental & Quality function deployment environmental \\
\hline
\end{tabular}

Table 2. Accessed data bases.

\begin{tabular}{|l|l|}
\hline \multicolumn{1}{|c|}{ Data base } & \multicolumn{1}{c|}{ URL } \\
\hline Compendex & http://www.engineeringvillage2.org \\
\hline IEEE & http://ieeexplore.ieee.org \\
\hline Science Direct & http://www.sciencedirect.com \\
\hline Emerald & http://www.emeraldinsight.com \\
\hline Web of Science & http://isiknowledge.com \\
\hline Google Scholar & http://scholar.google.com.br \\
\hline Scielo (Brazilian) & http://www.scielo.org \\
\hline
\end{tabular}

to identify eco-design methods available in the literature related to QFD.

Secondly, using the strings, a literature search was conducted whose main targets were publications in various data bases, such as Compendex, Science Direct, and Web of Science (Table 2).

Finally, the main criterion used to select the articles on QFD was based on only those methods related to new product/service development that considered environmental issues. All selected articles were then recorded in a spreadsheet for further analysis. The analysis considered some basic QFD characteristics based on the literature (AKAO, 1990; CAUCHICK MIGUEL, 2008; CHENG; MELO FILHO, 2007). This allows checking if those ecodesign methods may be considered as QFD in the sense of its concepts and characteristics.

\section{Synthesis of eco-design methods based on QFD}

As mentioned in the introduction, after conducting a systematic literature review, 17 eco-design methods based on QFD were identified, from 1993 to 2009. Table 3 presents a general profile of the publications and Table 4 shows important aspects of eco-design methods proposed by the literature. Each of them is outlined next in a chronological order.

The first method identified in the literature was proposed by Hochman and O'Connell (1993). The authors claim that the method aims at improving quality, speed, and costs of implementation of eco-design initiatives, i.e. reduction of environmental impacts in the product life-cycle. This proposal presents very few differences to traditional QFD matrix; the environmental requirements are present in the matrix together with product specifications.
Green QFD-II was developed by Zhang, Wang and Zhang (1999) with the objective of integrating environmental and cost issues to QFD matrices. It uses life-cycle cost (LCC) and life-cycle assessment (LCA). Green QFD-II also proposes a concept selection matrix that relates conventional product specifications, environmental issues, and costs as well as analyses those requirements together and individually.

QFDE by Masui, Sakao and Inaba (2001) is one of the most cited methods in the subject of environmental QFD. It is basis of other publications such as '3D-QFDE', 'Eco-VOC', integration 'QFDE/LCA' and 'QFDE/LCA/ TRIZ'. Its objective is to identify which functions and components must be prioritized to satisfy a customer concerned with environmental issues in addition to help engineers who are not familiar with environmental sciences. As a fundamental difference, QFDE presents a set of 15 environmental requirements and 15 engineering measures that must be incorporated to demanded quality and quality characteristics.

Wong and Juniper (2002) developed the Green Quality Function Deployment (GQFD). It relates environmental requirements and demanded quality to product specifications. This proposal points out the importance of considering all stakeholders in the process of obtaining VoC (Voice of Customer). However, it does not present significant differences with traditional QFD.

Rahimi and Weidner (2002) propose the QFD-DfE. It aims at relate customer requirements, cost reduction, and environmental impacts with design characteristics, considering the product life-cycle. Its application involves three distinct phases of design: to define product as a whole, its components, and product attributes. Although the QFDDfE considers environmental issues and costs, similarly to Green-QFD II, it differentiates because do not use LCC and LCA as in ref. (ZHANG; WANG; ZHANG, 1999).

Kato and Kimura (2003) developed the Environmental QFD to systematize environmental and technological issues. Quality demanded is divided into 3 types of requirements: user, social, and company's. The last one is related to environmental requirements. Quality characteristics are also divided into groups and related to the phase of product life-cycle: definition of raw material, design, manufacturing, sales, usage, recycling, and reverse logistics. 
Table 3. Demographics of the publications.

\begin{tabular}{|c|c|c|c|}
\hline Year & Author(s) & Source & Origin \\
\hline 1993 & Hochman and O'Connell & IEEE & USA \\
\hline 1999 & Zhang, Wang and Zhang & International Journal Production Research & USA \\
\hline 2001 & Masui, Sakao and Inaba & IEEE & Japan \\
\hline 2002 & Wong and Juniper & $8^{\text {th }}$ International Interdisciplinary Conference on the Environment & Australia \\
\hline 2002 & Rahimi and Weidner & The Journal of Sustainable Product Design & USA \\
\hline 2003 & Kato and Kimura & Proceedings of EcoDesign Conference & Japan \\
\hline 2003 & Yim and Hermann & Proceedings of EcoDesign Conference & Germany \\
\hline 2003 & Ernzer, Matthei, and Birkhofer & Proceedings of EcoDesign Conference & Germany \\
\hline 2003 & Sakao, Watanabe and Shimomura & Proceedings of EcoDesign Conference & Japan \\
\hline 2003 & Ernzer and Birkhofer & The $1^{\text {st }}$ international workshop on sustainable consumption & Germany \\
\hline 2005 & Shih and Liu & IEEE & Taiwan \\
\hline 2005 & Sakao et al. & 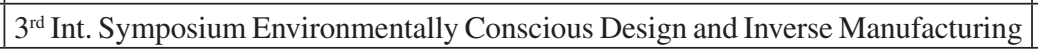 & Japan \\
\hline 2007 & Cagno and Trucco & Int. J. Product Life-cycle Man & Italy \\
\hline 2007 & Sakao & Int. J. Production Research & Germany \\
\hline 2008 & Wolniak and Sędek & Quality and Quantity (research note) & Poland \\
\hline 2009 & Kuo, Wu and Shieh & Expert Systems Application & Taiwan \\
\hline 2009 & Utne & Journal of Cleaner Production & Norway \\
\hline
\end{tabular}

Table 4. Eco-design methods based on QFD.

\begin{tabular}{|l|l|l|}
\hline Year & \multicolumn{1}{|c|}{ Author(s) } & \multicolumn{1}{c|}{ Highlights } \\
\hline 1993 & Hochman and O'Connell & Adaptation of traditional QFD by considering some environmental requirements \\
\hline 1999 & Zhang, Wang and Zhang & Green QFD-II based on life-cycle cost and life-cycle assessment \\
\hline 2001 & Masui, Sakao and Inaba & QFDEnvironment identifies functions and components to be prioritized \\
\hline 2002 & Wong and Juniper & Green QFD relates environmental requirements, demanded quality and specifications \\
\hline 2002 & Rahimi and Weidner & QFD-DfE relates customer satisfaction, cost reduction and environmental impacts \\
\hline 2003 & Kato and Kimura & Environmental QFD systematizes environmental with technological requirements \\
\hline 2003 & Yim and Hermann & Eco-VOC tries to identify the 'voice of environmental customer' ('eco-voice') \\
\hline 2003 & Ernzer, Matthei and Birkhofer & EI2QFD obtains the 'voice of the environment' through 'eco-Indicator 99 \\
\hline 2003 & Sakao, Watanabe and Shimomura & QFD is based on a 'receive state parameter' to design environmental conscious services \\
\hline 2003 & Ernzer and Birkhofer & Eco-QFD deploys market demands into product environmental requirements that \\
\hline 2005 & Shih and Liu & 3D QFDE analyses $n$ product design under the perspective of the environment \\
\hline 2005 & Sakao et al. & QFD/LCA proposes to integrate life-cycle assessment into QFDE \\
\hline 2007 & Cagno and Trucco & IGQFD simplifies Green-QFD II by excluding cost analysis \\
\hline 2007 & Sakao & QFDE/LCA/TRIZ applies life-cycle assessment and TRIZ to QFDE \\
\hline 2008 & Wolniak and Sędek & QFD Environmental identifies critical environmental parameters \\
\hline 2009 & Kuo, Wu and Shieh & Eco-QFD applies fuzzy logic to value environmental customer requirements and others \\
\hline 2009 & Utne & Eco-QFD aims at improving environmental performance of fishing fleet \\
\hline
\end{tabular}

A new contribution presented by authors is the use of 'quantification theory type IV' that allows to analyze matrix results in a bi-dimensional diagram. Figure 1 illustrates some aspects of that research.

Eco-VoC was developed from QFDE by Yim and Hermann (2003). Its objective is to present an alternative that facilitates the identification of "environmental voice of customer', called 'eco-voice'. The stage of extracting the eco-voice is based on 3 steps. After defining the environmental voice of customer, the authors (YIM; HERRMANN, 2003) propose the use of a simplified version of QFDE from Masui, Sakao and Inaba (2001).
EI2QFD is presented by Ernzer, Matthei and Birkhofer (2003) and aims at obtaining the 'voice of environment'. It is obtained from a method called 'eco-indicator 99' commonly used in life-cycle assessment. The voice of environment represents environmental issues need for a product. To do so, the proposal uses a QFD structure that consists of two 'environmental matrices'. Both of matrices establish as demanded quality the results from eco-indicator 99; the first group comprises requirements related to the stage of usage (first matrix) and production requirements as well as end of life for second matrix. 


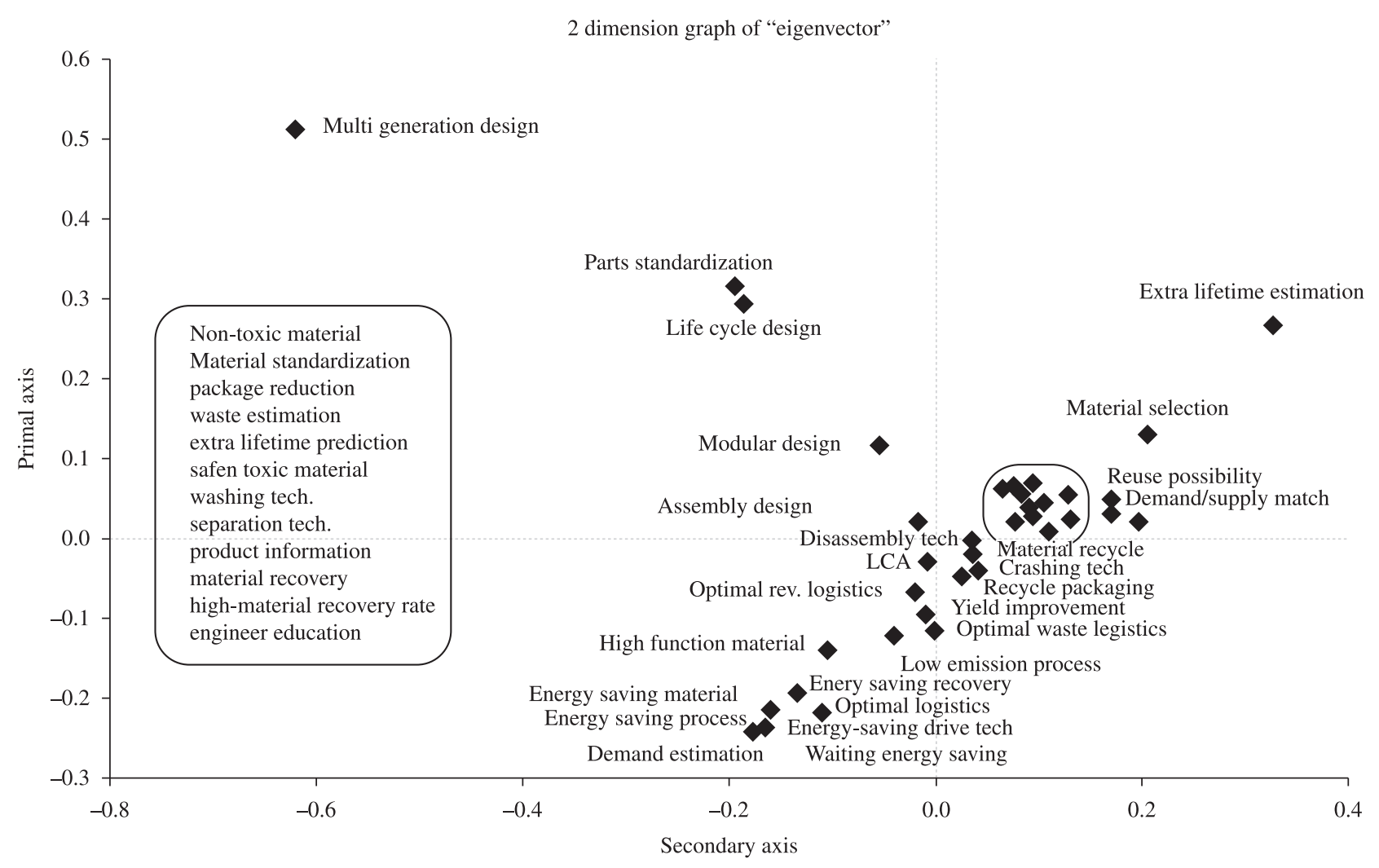

Figure 1. Quantification of requirements in the environmental QFD (KATO; KIMURA, 2003).

Sakao, Watanabe and Shimomura (2003) presents a method that considers RSP or 'Receive State Parameter' whose objective is to design services with environmental conscious by using QFD. Therefore, the main contribution of that proposal is to design services that are more environmentally suitable.

Ernzer and Birkhofer (2003) propose a method based on QFD, called of 'eco-QFD' to deploy market needs into design requirements that take into account product environmental issues. The structure of eco-QFD is not different from traditional QFD with regard to the way of applying it.

3D QFDE is published by Shih and Liu (2005). It is another method that is based on QFDE proposed by Masui, Sakao and Inaba (2001). It analyses a number of product designs under 3 distinct perspectives: quality, costs, and environmental issues. The results from product designs considering the 3 perspectives are plotted in a pyramidal form, where each vertice represents quality, costs, and environmental issues in order to assist in selecting the best product design.

The proposal of Sakao et al. (2005) aim at integrating life-cycle assessment to QFDE. Therefore, QFDE is to be used in the initial stages of new product development and, as soon more data and information are available, a qualitative assessment of environmental impacts is calculated through life-cycle assessment.

Cagno and Trucco (2007) developed a QFD environmental method that fixes the limitations of Green-QFD II. The main changes consist of excluding cost analysis and simplifying life-cycle assessment. The quality matrix is then divided into 4 parts, where the voice of customer is related to quality function and to the environmental goals as well as the voice of environment is related to quality function and to the environmental goals.

Similarly to the integration of QFDE to quality functions and life-cycle assessment, the proposal by Sakao (2007) tries to integrate life-cycle assessment and TRIZ (Theory of Inventive Problem Solving) to QFDE. Life-cycle assessment is initially used in early product design when customer and environmental issues and its impacts are determined. This is followed by phases I and II of QFDE, i.e. when quality product characteristics are defined. TRIZ is applied in the third phase in the search of design solutions. Phases III and IV of QFDE are then applied in the product concept evaluation, followed by phase $\mathrm{V}$ that is applied in the product detainment. Finally, life-cycle assessment is applied again to evaluate the proposed environmental improvements.

Wolniak and Sędek (2008) present a version of environmental QFD to list ecological information to product and service alternatives. From this relation it 
identifies critical parameter under the point of view of the environment. Practically, there is no difference when comparing the proposal to traditional QFD, except for some requirements that are exclusively environmental issues that may be applied either to products or services.

Kuo, Wu and Shieh (2009) developed an environmental QFD that uses fuzzy logic to help in identifying and weight the level of importance of customer requirements either environmental or not. Each demanded quality is evaluated and transformed in a fuzzy output. This task is carried out by a group of experts. Those requirements are related to product specifications (quality characteristics) in the different stages of product life-cycle, namely: definition of raw material, design and manufacturing, distribution, usage and recycling.

Utne (2009) also proposes a method based on QFD. According to the author the main objectives are: to have a performance improvement of fishing fleet are well as to help management activities. This is accomplished by considering environmental issues, costs, and stakeholders.

\section{Analysis of eco-design methods based on QFD}

Before discussing the methods described in the previous section, the main characteristics of QFD is established. Those are important to be used for conducting the analysis.

Conceptually, QFD is a method that allows assuring quality in each stage of new product development with the objective of customer satisfaction by translating demanded quality into design goals (AKAO, 1990). As extensively established in the literature, the quality matrix is an important part of the method to relate demanded quality with quality characteristics. In doing so, there exist other elements which are also relevant such as the level of importance given to the demanded quality by customers, commercial benchmarking, quality planning as well as the design quality to prioritize product specifications (quality characteristics).

Quality matrix (also referred to 'house of quality' in the literature) is not the whole QFD. Quality Function Deployment is a generic name for quality deployment and narrowly defined quality function deployment. Quality deployment is defined as translating the user demands into substitute characteristics (quality characteristics), determining the design quality of a completed product, and systematically deploying the quality of each product system into that of each component and processes as well as the relationship among them. Narrowly defined QFD is defined as systematically deploying the job functions and operations that contribute to quality into step-by-step details. Figure 2 illustrates QFD definition by Akao (1998).

Quality deployment is the first step in QFD by initiating from quality matrix and others may be in place to deploy quality throughout the stages of product development (AKAO, 1998). Nevertheless, the application of QFD

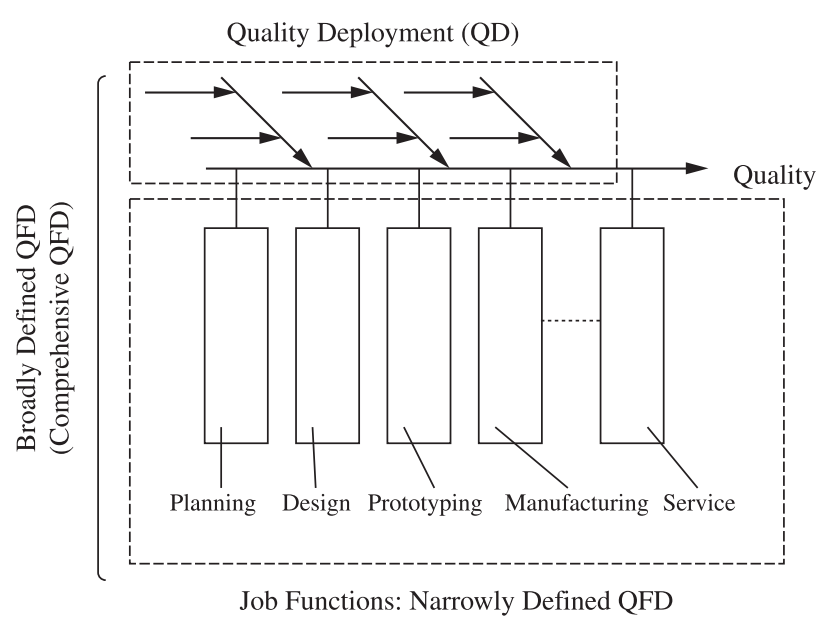

Figure 2. Definition of QFD (AKAO, 1998).

usually emphasizes the quality matrix as in the 17 eco-design methods proposed in the literature. Therefore, some important characteristics in the quality matrix were selected to analyze those proposals, namely: quality planning, design quality, deployment, etc. Those characteristics usually found in the traditional QFD applications were then considered in the analysis. To do so, a matrix was developed to compare the 17 eco-design methods, as showed in Table 5.

As can be seen in Table 5, none of the 17 eco-design methods presented all 5 QFD characteristics. The eco-design method more loyal to traditional QFD is the one of Hochman and O'Connell (1993), as expected since it is the oldest one published. Along the years, the others changed compared to original QFD from Akao (1990). Nevertheless, they incorporated other tools and techniques to be integrated into concepts such as life-cycle assessment, fuzzy logic, and TRIZ. Very few eco-design methods considered deployments so they are not properly QFD in essence but an application of only one matrix, which could be necessary but not enough.

Other issues are identified in the eco-design methods. One is the amount of data used for some of them. In the example of 'Environmental QFD' (KATO; KIMURA, 2003) 27 demanded quality items and 40 quality characteristics are presented that lead to 1,080 possible relations, which may be time-consuming. Some eco-design methods are prescriptive since they suggest a list of environmental demanded quality and/or quality characteristics, e.g. Masui et al. (2001). Although this could be useful it can also be a drawback since those requirements are not, in fact, developed. The more suitable thing to do would be to encourage the team to identify those requirements from the main stakeholders.

The use of more complex tools are usually welcome, e.g. life-cycle assessment, fuzzy logic, and so on. The downside is that may bring inherent difficulties to those who are not familiar with them. Sometimes, users who dot not know how 
Table 5. Analysis of eco-design methods based on QFD.

\begin{tabular}{|c|c|c|c|c|c|c|}
\hline \multirow[b]{2}{*}{ Ecodesign methods basedon QFD } & \multicolumn{5}{|c|}{ Tradicional QFD characteristics } & \multirow{2}{*}{$\begin{array}{c}\text { Rating of } \\
\text { ecodesign } \\
\text { methods based } \\
\text { on QFD }\end{array}$} \\
\hline & $\begin{array}{l}\text { Quality } \\
\text { planning }\end{array}$ & $\begin{array}{l}\text { Design } \\
\text { quality }\end{array}$ & $\begin{array}{l}\text { Deployment } \\
\text { in phases }\end{array}$ & $\begin{array}{c}\text { Correlation } \\
\text { of technical } \\
\text { requirements }\end{array}$ & $\begin{array}{c}\text { VOC } \\
\text { deployment } \\
\text { in levels }\end{array}$ & \\
\hline QFD (HOCHMAN; O'CONNELL, 1993) & $\mathrm{V}$ & V & $\mathrm{X}$ & $\mathrm{V}$ & $\mathrm{V}$ & 4 \\
\hline Green QFD-II (ZHANG et al., 1999) & $\mathrm{X}$ & $\mathrm{X}$ & $\mathrm{X}$ & $\mathrm{V}$ & $\mathrm{X}$ & 1 \\
\hline QFDE (MASUI et al., 2001) & $\mathrm{X}$ & $\mathrm{X}$ & $\mathrm{V}$ & $\mathrm{X}$ & $\mathrm{X}$ & 1 \\
\hline GQFD (WONG; JUNIPER, 2002) & $\mathrm{V}$ & $\mathrm{V}$ & $\mathrm{X}$ & $\mathrm{V}$ & $\mathrm{X}$ & 3 \\
\hline QFD-DfE (RAHIMI; WEIDNER, 2002) & $\mathrm{X}$ & $\mathrm{X}$ & $\mathrm{X}$ & $\mathrm{V}$ & $\mathrm{X}$ & 1 \\
\hline Environmental QFD (KATO; KIMURA, 2003) & $\mathrm{V}$ & $\mathrm{X}$ & $\mathrm{X}$ & $\mathrm{X}$ & $\mathrm{X}$ & 1 \\
\hline Eco-VOC (YIM; HERMANN, 2003) & $\mathrm{X}$ & $\mathrm{X}$ & $\mathrm{X}$ & $\mathrm{X}$ & $\mathrm{V}$ & 1 \\
\hline EI2QFD (ERNZER et al., 2003) & $\mathrm{X}$ & $\mathrm{X}$ & $\mathrm{X}$ & $\mathrm{X}$ & $\mathrm{V}$ & 1 \\
\hline $\begin{array}{l}\text { QFD based on RSP } \\
\text { (SAKO; WATANABE; SHIMOMURA, 2003) }\end{array}$ & $\mathrm{X}$ & $\mathrm{X}$ & $\mathrm{X}$ & $\mathrm{X}$ & $\mathrm{X}$ & 0 \\
\hline Eco-QFD (ERNZER; BIRKHOFER, 2003) & $\mathrm{X}$ & $\mathrm{X}$ & $\mathrm{X}$ & $\mathrm{X}$ & $\mathrm{V}$ & 1 \\
\hline 3D-QFDE (SHIN; LIU, 2005) & $\mathrm{X}$ & $\mathrm{X}$ & $\mathrm{X}$ & $\mathrm{X}$ & $\mathrm{X}$ & 0 \\
\hline Integration QFDE/LCA (SAKAO et al., 2005) & $\mathrm{X}$ & $\mathrm{X}$ & $\mathrm{V}$ & $\mathrm{X}$ & $\mathrm{X}$ & 1 \\
\hline IGQFD (CAGNO; TRUCCO, 2007) & $\mathrm{V}$ & $\mathrm{X}$ & $\mathrm{X}$ & $\mathrm{V}$ & $\mathrm{X}$ & 2 \\
\hline Integration QFDE/LCA/TRIZ (SAKAO, 2007) & $\mathrm{X}$ & $\mathrm{X}$ & $\mathrm{V}$ & $\mathrm{X}$ & $\mathrm{X}$ & 1 \\
\hline QFD (WOLNIAK; SĘDEK, 2008) & $\mathrm{X}$ & $\mathrm{X}$ & $\mathrm{X}$ & $\mathrm{V}$ & $\mathrm{X}$ & 1 \\
\hline Eco-QFD (KUO, 2009) & $\mathrm{X}$ & $\mathrm{X}$ & $\mathrm{X}$ & $\mathrm{X}$ & $\mathrm{X}$ & 0 \\
\hline Eco QFD (UTNE, 2009) & $\mathrm{V}$ & $\mathrm{X}$ & $\mathrm{X}$ & $\mathrm{V}$ & $\mathrm{X}$ & 2 \\
\hline $\begin{array}{l}\text { \# of QFD characteristics found on the ecodesign } \\
\text { methods }\end{array}$ & 5 & 2 & 3 & 7 & 4 & \\
\hline
\end{tabular}

$\mathrm{V}$ - shows at least in part. X - shows nothing.

to apply them may choose not to deal with them. It can be observed that some eco-design methods may not deliver the environmental benefits they promise. It is well-known that some products do have environmental impacts in their use, e.g. a washing machine. So, not considering it in the stage of usage of a product is not suitable like the one showed by Masui et al. (2001). In addition, the eco-design method proposed by Wolniak and Sędek (2008) establishes some environmental requirements too general, e.g. 'air pollution'. This requirement may occur from a number of sources (e.g. fossil fuels, industrial activities, painting, etc.). The lack of defining a requirement more precisely (further deployments) may lead to incomplete or wrong decisions in new product development.

\section{Conclusions}

Under the emerging demand of developing eco-products, the development of eco-design is welcome. In this sense, current work presented eco-design methods found in a systematic literature review. Almost all eco-design methods cannot be considered as extensions of traditional QFD methodology. They do try to translate demanded environmental issues into design specification but, most of them are, in fact, simplified versions of a quality matrix where environmental requirements are introduced. Reaching environmental improvement with those methods is also questionable. This is due to a number of reasons such as over complexity, no consideration of some phases of product life-cycle (especially with regard to the $\mathrm{VoC}$ ) or the use of generic terms to represent environmental issues. Another issue is that the effort for carrying the eco-design methods may be long and time consuming. A concluding point that rose is that most publications are theoretically weak and, in some cases, empirically as well. Based on the current analysis, future work will involve further development of QFD applied to eco-design methods in an attempt to contribute to environmental studies.

\section{References}

AKAO, Y. Quality function deployment: Integrating customer requirements into product design. Cambridge: Productivity Press, 1990.

AKAO, Y. QFD Concepts. In: ADVANCED QFD COURSE, 1998, Novi. Proceedings... Novi, Michigan: QFD Institute, 1998.

BAKKER, C. Environmental Information for Industrial Designers. Delft, Netherlands: Delft University of Technology, 1995. 
BIOLCHINI, J. et al. Systematic Review in Software Engineering. Rio de Janeiro: COPPE, 2005. (Technical Report RT - ES 679/05).

BOVEA, M. D.; WANG, B. Redesign Methodology for Developing Environmentally Conscious Products. International Journal of Production Research, v. 45, p. 40574072, 2007. http://dx.doi.org/10.1080/00207540701472678

CAGNO, E.; TRUCCO, P. Integrated green and quality function deployment. International Journal of Product Lifecycle Management, v. 2, n. 1. p. 64-83, 2007. http:// dx.doi.org/10.1504/IJPLM.2007.012875

CAUCHICK MIGUEL, P. A. Implementing QFD for New Product Development. São Paulo: Editora Atlas, 2008.

CHENG, L. C.; MELO FILHO, L. R. QFD - Quality Function Deployment in the Produc Development Management. São Paulo: Edgard Blücher, 2007.

ERNZER, M.; BIRKHOFER, H. How to carry out lifecycle design?: Methodical support for product developers. Darmstadt, Germany: Darmstadt University of Technology, 2003.

ERNZER, M.; MATTHEI, C.; BIRKHOFER, H. EI2QFD - an Integrated QFDApproach or From the Results of Eco-indicator 99 to Quality Function Deployment. In: INTERNATIONAL SYMPOSIUM ON ENVIRONMENTALLY CONSCIOUS DESIGN AND INVERSE MANUFACTURING, 3., 2003, Tokyo, Japan. Proceedings... Tokyo: IEEE, 2003.

HOCHMAN, S.; O'CONNELL, P. Quality Function Deployment: Using the Customer to Outperform the Competition on Environmental Design. IEEE, 1993.

KATO, S.; KIMURA, F. Systematization of Product Life Cycle Technology Utilizing the QFD Method. In: INTERNATIONAL SYMPOSIUM ON ENVIRONMENTALLY CONSCIOUS DESIGN AND INVERSE MANUFACTURING, 3., 2003, Tokyo, Japan. Proceedings... Tokyo: IEEE, 2003.

KNIGHT, P.; JENKINS, J. O. Adopting and applying ecodesign techniques: a practitioners perspective. Journal of Cleaner Production, v. 17, p. 549-558, 2009. http://dx.doi. org/10.1016/j.jclepro.2008.10.002

KUO, T-C., WU, H-H.; SHIEH, J-I. Integrating of environmental considerations in quality function deployment by using fuzzy logic. Expert Systems with Applications, v. 36, p. 71487156, 2009. http://dx.doi.org/10.1016/j.eswa.2008.08.029

MASUI, K., SAKAO, T.; INABA, A. Quality Function Deployment for Environment: QFDE (1st Report) - A Methodology in Early Stage of DfE. In: INTERNATIONAL SYMPOSIUM ON ENVIRONMENTALLY CONSCIOUS DESIGN AND INVERSE MANUFACTURING, 2., 2001, Tokyo, Japan. Proceedings... Tokyo: IEEE, 2001.
RAHIMI, M.; WEIDNER, M. Integrating Design for Environment (DfE) Impact Matrix into Quality Function Deployment (QFD) Process. The Journal of Sustainable Product Design, v. 2, p. 29-41, 2002. http://dx.doi. org/10.1023/B:JSPD.0000016418.79201.e7

RITZEN, S.; LINDAHL, M. Selection and implementation - Key activities to successful use of Ecodesign tools. In: INTERNATIONAL SYMPOSIUM ON ENVIRONMENTALLY CONSCIOUS DESIGN AND INVERSE MANUFACTURING, 2., 2001, Tokyo, Japan. Proceedings... Tokyo: IEEE, 2001.

SAKAO, T. A QFD-centred design methodology for environmentally conscious product design. International Journal of Production Research, v. 45, n. 18-19, pp 41434162, 2007. http://dx.doi.org/10.1080/00207540701450179

SAKAO, T., WATANABE, K.; SHIMOMURA, Y. A Method to Support Environmentally Conscious Service Design Using QFD. In: INTERNATIONAL SYMPOSIUM ON ENVIRONMENTALLY CONSCIOUS DESIGN AND INVERSE MANUFACTURING, 3., 2003, Tokyo, Japan. Proceedings... Tokyo: IEEE, 2003.

SAKAO, T. et al. QFDE (Quality Function Deployment for Environment) and LCA: An effective combination of tools for DfE. In: INTERNATIONAL SYMPOSIUM ON ENVIRONMENTALLY CONSCIOUS DESIGN AND INVERSE MANUFACTURING, 3., 2003, Tokyo, Japan. Proceedings... Tokyo: IEEE, 2005.

SHIH, L.; LIU, B. Evaluating Eco-Design Projects with 3D-QFDE: Method and Life Cycle Cost Estimation. IEEE, 2005.

UTNE, I. B. Improving the environmental performance of the fishing fleet by use of Quality Function Deployment (QFD. Journal of Cleaner Production, v. 17, p. 724-731, 2009. http://dx.doi.org/10.1016/j.jclepro.2008.11.005

WONG, K.; JUNIPER, J. Quality Function Deployment (QFD) and the Environment. In: INTERNATIONAL INTERDISCIPLINARY CONFERENCE ON THE ENVIRONMENT, 8., 2002, Toronto, Canada. Proceedings... Toronto: Interdisciplinary Environmental Association, 2002. p. 80-87.

WOLNIAK, R.; SĘDEK, A. Using QFD method for the ecological designing of products and services. Quality and Quantity, v. 3, n. 4, p. 695-701, 2008.

YIM, H.; HERRMANN, C. Eco-Voice of Consumer (VOC) on QFD. In: INTERNATIONAL SYMPOSIUM ON ENVIRONMENTALLY CONSCIOUS DESIGN AND INVERSE MANUFACTURING, 3., 2003, Tokyo, Japan. Proceedings... Tokyo: IEEE, 2003.

ZHANG, Y.; WANG, H.; ZHANG, C. Green QFD-II: a life cycle approach for environmentally conscious manufacturing by integrating LCA and LCC into QFD matrices. International Journal of Production Research, v. 37, n. 5, p. 1075-1091, 1999. http://dx.doi.org/10.1080/002075499191418 